\title{
SME Business Development Strategy Model in Tuban Regency, Indonesia: SWOT \& EFE-IFE Analysis
}

\author{
Iha Haryani Hatta ${ }^{1}$, Hindrajid Harsono ${ }^{2}$ \\ \{ Iha.suryanihatta@yahoo.com ${ }^{1}$ \} \\ ${ }^{1,2}$ Faculty of Economics and Business, Pancasila University, Lenteng Agung Street, Depok, Indonesia
}

\begin{abstract}
SMEs of marine fish processing in Tuban Regency, Indonesia need to be developed considering the skills to manage business (employees, production, finance, external, and marketing strategies) and the achievement level of marketing performance are not yet optimal. In addition, most of these SME entrepreneurs are young and have low education. Therefore, the study on the SME business development strategy model in Tuban Regency, Indonesia is needed using the SWOT and EFE-IFE analysis, which aims to identify the models and recommendations of the SME business development strategy. The study interviewed 40 SMEs entrepreneurs engaged in marine fish processing as random respondents. The results of the study explain that this business development strategy model is S-T. This means that these business entrepreneurs will optimize the strengths they have in order todeal with the existing obstacles. Therefore, the strategic recommendations for these SMEs include developing competitiveness and improving good relations with customers.
\end{abstract}

Keywords: Business development strategy, SWOT, IFE-EFE Analysis.

\section{Introduction}

Business in the marine and fisheries sector in Indonesia has good prospects to encourage accelerated economic growth. Indonesia has the opportunity to become the world's largest producer of fishery products because fisheries contribution from year to year has increased.

Tuban Regency is the regency in East Java Province with the largest number of SMEs processing fishery products. Fish processing activities in the regency include processing of fresh fish, freezing, salting/drying, salting and seasoning, smoking, and other processing such as shrimp paste, crackers, and petis. These business activities are generally still dominated by micro, small and medium scale enterprises with all the problems they have, including: innovation capability, capital shortage, lack of technology and information, management and marketing, and the location spread. To optimize the potential of marine and fisheries resources and make this sector a prime mover of national economic development in Tuban Regency, efforts are needed to accelerate and breakthrough in the development of marine and fisheries supported by political and economic policies and a conducive social climate, especially Micro Small Medium Enterprise (MSME). MSME needs to get attention as it is a national struggle tool to grow and develop the economy by involving as many economic practitioners as possible based on their potential on the basis of justice for all stakeholders (Rio \& Susilawati, 2016; 7).

According to Aldo (2015, 185-194), business is all activities to produce goods and services aiming to gain profits. Meanwhile, the business development strategy is the creation of long-term value for consumers and the market related to the task and analytical preparation process on potential growth opportunities and assistance for the implementation process of 
growth opportunities, but does not include decision making, formulation, and direct implementation of growth opportunities. To make decisions on business development, business developers and strategies for decision-making are needed. The study results by Arslan et al (2013. 91-98) explain, among others, the impact of pre-job evaluation in assessing SWOT analysis appearing to be positive for effective strategic marketing planning.

\section{The Oretical Basis}

The variables of this study include strengths, weak-nesses, opportunities, and obstacles. According to Dwi Fatimah FN, (2016: 13), strengths are in the form of natural resources, skills, or other advantages related to company competitors and market needs that can be served by companies that they expect to serve. Strength is a special competition that provides a competitive advantage for companies in the market. Weaknesses are in the form of limitations or shortcomings in natural resources, skills, and capabilities that effectively inhibit the company's performance. These limitations include facilities, finances, management capabilities, and marketing skills. Opportunities are in the form of important situations that are beneficial in the company environment. Important trends are one source of opportunity, such as technological change and increased relations between companies and buyers or suppliers. Threats are in the form of important unfavorable situations in the company environment. The existence of new or revised government regulations can be a threat to the company's success.

According to Rangkuti Freddy $(2016,24)$, the evaluation of internal factors (IFE) consists of 2 things, strengths and weakness ( $\mathrm{S}$ and $\mathrm{W})$. These factors are related to the conditions that occur in the company, which also influence the formation of decision making by the company. According to Joko et al (2015, 60-71), internal factors include marketing, human resources, finance/accounting, production/operations etc. Meanwhile, according to Fandy and Gregorius $(2012,193)$, marketing strategy is a plan that describes the company's expectations of the impact of various marketing activities or programs on product demand or product lines in a particular target market. According to Gary Dessler $(2016,5)$, human resource management is the process of obtaining, training, assessing, and compensating employees, paying attention to their work relationships, health, security and justice issues. According to Kasmir $(2010,5)$, financial management is all activities related to acquisition, funding, and asset management with several overall objectives. Meanwhile, according to Sofjan Assauri $(2016,6)$, the management of production operations is a collection of activities related to the creation of value of goods, services, and ideas, by transforming input into output.

According to Rangkuti Freddy $(2016 ; 24)$, evaluation of external factors (EFE) consists of 2 things, opportunities and threats $(\mathrm{O}$ and $\mathrm{T})$. These factors are related to conditions that occur outside the company that influence the company's decision making. According to Joko et al (2015, 60-71), external factors include economic strength, social, cultural, demographic and environmental strength, political power of government and law, technological strength, and competitive strength. So, before a strategy is implemented, strategic planning must analyze the external environment to find out various possible opportunities and obstacles.

Meanwhile, the company's strategy is always directed to produce good marketing performance (sales volume, sales growth rate, and market share). According to Ferdinand $(2000,23)$ marketing performance is a factor that is often used to measure the impact of the strategy implemented by the company. 


\section{Methodology}

The population used in this study is SMEs of marine fish processing in Tuban Regency, East Java. The sample used is 40 random SMEs of marine fish processing. Other primary data are in the form of interviews with officials of the Marine Service and 10 other SMEs. So that a more in-depth study discussion is obtained.

The measuring instrument in this study is a questionnaire consisting of statements with alternative closed-ended answers on a Likert scale, namely the value of 1 (disagree), 2 (neither agree nor disagree/neutral), and 3 (agree). The level of the variable value is based on the calculation (the highest value - the lowest value)/the highest value, namely $(3-1) / 2=0.67$, $1.00-1.67=$ low, $1.68-2.34=$ moderate, and $2.35-3.00=$ high

Data is analyzed by SWOT. According to Gomatesh and Poornima (2012, 2-9), SWOT analysis method has been widely used as a toll for planning and analyzing strategic actions over the past decade. According to Dijana Oreski (2012, 283-291), SWOT is an acronym of strength, weakness, opportunities, and threats. According to Nura and Garba (2013, 83-91), SWOT is a system or process of considering the internal and external factors affecting the performance of an organization in relation to competitor or market situation.

According to Xia Chan (2011, 147-153), SWOT is carried out in the following steps. First, analyze business's external environments to find out strengths and weaknesses of business processes. Third, allocate external opportunities and threats with internal strengths and weaknesses. See Tables 1 and 2.

According to Rangkuti Freddy (2016; 83), the tool used to develop a business development strategy is a SWOT matrix consisting of External Factor Evaluation (EFE) and Internal Factor Evaluation (IFE). There are 4 alternative business development strategies based on the SWOT analysis, namely: S-O Strategy. This condition is very favorable, namely the system has good strengths and opportunities. The S-O strategy is developed based on the company's mindset, i.e. by utilizing all the strengths and opportunities as much as possible. Meanwhile, S - T Strategy has strengths but faces various threats. This strategy is developed using the strengths of the company to overcome threats. The right strategy is a diversification strategy, which uses power to take advantage of long-term opportunities. The W-O strategy has good opportunities, but is constrained by internal weaknesses. This strategy is implemented by minimizing existing weaknesses and utilizing opportunities. The right strategy is to minimize internal problems, so as to seize external opportunities better. The $\mathrm{W}$ $\mathrm{T}$ Strategy has very unfavorable conditions. This strategy is based on activities that are defensive; try to minimize the existing weaknesses and avoid threats.

The strategy recommendations that can be implemented based on SWOT conditions (Nur, 2013): Recommendations for S-O strategy include maintaining and improving product quality as well as after-sales service, developing middle to lower market, and conducting exhibition activities; the $\mathrm{W}-\mathrm{O}$ Strategy includes targeted promotion, more vigorous promotion by holding, following, or sponsoring events, promoting through printed media, and social networking media, and adding to the sales network; The $\mathrm{S}-\mathrm{T}$ Strategy includes developing competitiveness and enhancing good relationships with customers; The W - T Strategy includes expanding the promotion area to expand the sales network, increasing sales variations that are trend in the community, and providing price discounts for loyal consumers.

\section{Result And Discussion}

Respondents for this study are 40 SME entrepreneurs of marine fish processing. The characteristics of the respondents are as follows: most respondents are women $(82.5 \%)$. Most 
of these SME entrepreneurs are young, $70.0 \%$ of respondents are less than 50 years old, even $7.5 \%$ of those respondents are less than 30 years old. Most respondents have low education, $62.5 \%$ of respondents have no primary school education and graduated from elementary school. Most respondents (65\%) are engaged in salted/dried fish business and fish smoking and drying. The small and medium-sized enterprises in marine fish processing in Tuban Regency do not need to be in legal entities. They have long been running SMEs in marine fish processing; most respondents $(80.0 \%)$ have been in business more than 8 years and even $32.5 \%$ of these respondents have been working in the fish processing field for more than 18 years. All respondents in this study were business owners. Marine fish processing business in Tuban Regency is not yet labor intensive. About 95\% of respondents employ 1-6 employees, even $67.5 \%$ of these respondents only have $1-3$ employees.

The management skills of the SME entrepreneurs in the marine fish processing in Tuban Regency is not yet optimal (medium). Their management skills in production, financial, external, and marketing strategies are medium as indicated in the skill index ranging 1.672.34. However, their employee management skill is low as indicated in the skill index of $\leq$ 1.67. Meanwhile, the marketing performance achievement in this business is not yet optimal (medium), as indicated in the skill index of $2.18(1.67-2.34)$. See table 1.

Table 1. Business Management Skills

\begin{tabular}{|c|c|c|}
\hline No. & Management & $\begin{array}{c}\text { Inde } \\
\mathrm{x}\end{array}$ \\
\hline 1. & Employees & 1.38 \\
\hline 2. & Production & 2.14 \\
\hline 3. & Finance & 1.79 \\
\hline 4. & External & 2.18 \\
\hline 5. & Marketing Strategy & 1.70 \\
\hline 6. & Marketing Performance & 2.18 \\
\hline & Average & 1.90 \\
\hline
\end{tabular}

The Results of the study by Ifediora et all (2014, 23-32), SWOT analysis however helped one of the two studied to advance in the face of growing challenges thereby leading to its stability and increased productivity. According to Alka Jain (2015, 31-34), he explains that the SWOT model of thirukkural is a complete analysis model of any problems that an entrepreneur may have to face while starting a new business.

In this study, the strengths that the SME entrepreneurs have in the marine fish processing in Tuban Regency include adequate inventory (S1), knowing the cost of working capital for production (S2), there are pricing and profit methods $(\mathrm{S} 3)$, able to face competition from other businesses (S4), and easily obtained (S5).

The weaknesses that the SME entrepreneurs of marine fish processing have include lack of employee planning (W1), employee recruitment process as needed (W2), written task assignment (W3), organization/coordination (W4), employee development (W5), inadequate wages/salary (W6), incentives (W7), other rewards (W8), lack of health insurance (W9), lack of clear working hours (W10), lack of work supervision (W11), lack of sanctions (W12), lack of machinery/equipment (W13), inconsistent work steps (W14), poor inventory (W15), no recording of any business transactions (W16), no computer assistance (W17), no business transaction documents (W18), there is no income and expenditure planning (W19), there is no separation between assets and debt of the business owner (W20), has not participated in 
financial report training (W21), has never borrowed money from a bank or financial institution (W22), money is not yet saved in the bank (W23), not always examine business finances (W24), not keeping up with technological developments (W25), there is no taste variation of the product (W26), there is no variation in packaging and size (W27), there is no quality raw material (W28), less attention to consumer health (W29), there is no variation in price (W30), there is no price list (W31), there is no transaction facility (W32), there is no promotional activity (W33), there are no promo offers (W34), and trademarks are not registered (W35), there is no profit growth compared to the previous year (W36), and there is no growth in sales volume compared to the previous year (W37).

The opportunities that the SME entrepreneurs have in Marine Fish Processing in Tuban Regency are: easy to get suppliers $(\mathrm{O} 1)$, the natural situation is supportive $(\mathrm{O} 2)$, the bargaining power of the buyers is relatively high (O3), the bargaining power of suppliers is relatiely high (O4), and there is no support from the Regency Government (O5).

Challenges faced by SME entrepreneurs in the marine fish processing in Tuban Regency include lack of support from BUMN (T1), lack of support from other parties (T2), there is no increase in the percentage of market share compared to the previous year (T3), the absence of an increase in consumer satisfaction compared to previous year (T4). Internal Factor Evaluation (IFE) Analysis is an internal environment analysis of SMEs consisting of two variables: strength and weakness variables. IFE score $=2.154$ which consists of a strength score $=1.508$ which is greater than the weakness score $=0.646$. This means that the SME entrepreneurs in managing their businesses have more strengths than weaknesses. IFE analysis can be seen in Table 2 .

External Factor Evaluation (EFE) Analysis is an external environment analysis of SMEs consisting of two variables: opportunities and challenges. EFE score $=2.231$ which consists of an opportunity score $=0.831$ which is smaller than the challenge score $=1.400$. This means that the SME entrepreneurs of marine fish processing in Tuban Regency have more challenges than opportunities in managing their businesses. See Table 3.

From Table 2 and 3, the information obtained is that the EFE score $=2.77$ is greater than the IFE score $=2.75$. This means that SME entrepreneurs in marine fish processing in Tuban Regency, East Java, put more priority on overcoming external factors rather than optimizing internal factors in running their business. Based on the weakness score $=2.36$ which is greater than the strength score $=0.39$ and the opportunity score $=1.50$, which is greater than the challenge score $=1.27$, then the future business development strategy for SMEs of marine fish processing in Tuban Regency, East Java is a W-O strategy, which is a strategy to minimize weaknesses to take advantage of opportunities. So that the strategy recommendations for these SMEs include targeted promotions, more vigorous promotion by holding, following, or as sponsors at various events, promotion through printed media, and social networking media, and increasing sales networks. Muatasim and Norlena (2015, 13-23), in their study explained that SWOT and EFE/IFE matrix is to analyze and investigate the implementation and adoption of e-Government in Oman using secondary data from statistical reports.

\section{Conclusions}

SMEs in marine fish processing in Tuban Regency will survive and can develop, therefore it needs to be developed. This is due to the fact that most entrepreneurs are young, despite their low education. However, their business management skills and marketing performance achievement is medium. Their skills in employee management, finance, and 
external businesses, and marketing strategy implementation are medium, and their ability to manage production is low.

SME entrepreneurs of marine fish processing in Tuban Regency put more priority on overcoming external factors rather than internal factors. This business development strategy model is $\mathrm{W}-\mathrm{O}$, meaning that it is necessary to minimize weaknesses first in order to take advantage of opportunities. Therefore, the strategy recommendations for these SMEs include targeted promotion, more vigorous promotion by holding, following, or becoming sponsors at various events, promotion through printed media, and social networking media, and increasing sales networks.

The central and regional governments, State-Owned Enterprises, universities and other parties have the interest in improving the welfare of the community, particularly the SME entrepreneurs of marine fish processing in Tuban Regency, East Java. The SME entrepreneurs need support to minimize their weaknesses in the followings: workers recruitment planning, workers search process based on needs, written task assignment, organization/coordination, workers development, inadequate wages, incentives, other rewards, lack of health insurance, lack of clear working hours, lack of job supervision, lack of sanctions, lack of machinery/equipment, inconsistent job steps, poor inventory, no recording of any business transactions, no computer assistance, no business transaction documents, no income and expenditure planning, no separation of assets and debts of business owners, not participating in financial report training, never borrowed money from banks or financial institutions, not saving money in the bank, not always checking business finances, not keeping up with technological developments, no taste variation of the products, no variety of packaging and size, lack of quality raw materials, lack of attention to the consumers health, the absence of variations in prices, the absence of price lists, the absence of transaction facilities, no promotional activities, no promo offers, trademarks not registered, no profit growth compared to the previous year, and there is no growth in sales volume compared to the previous year. Also the SME entrepreneurs need support to take advantage of opportunities by starting to implement workers searching processes according to needs, written task assignment, organization/coordination, workers development, other rewards, adequate machinery/equipment, records of each business transaction, income planning and expenditure, separation of owner and business assets and debts, borrowing money from banks or financial institutions, checking business finances, keeping up with technological developments, support from regency government, support from state-owned enterprises, other supports, variations in packaging and size, and price list.

\section{References}

[1] Aldo Hardi Sancoko. 2015. Strategi Pengembangan Bisnis Usaha Makanan dan Minuman Pada Depot Time to Eat Surabaya. Agora 3 (1); 185-194.

[2] Alka Jain. 2015. SWOT Analysis in Thirukkural: Comparative Analysis with Humphrey SWOT Matrix. IQSR Journal of Business and Management (IQSR-JBM) 7 (1) Ver. 2; 31-34.

[3] Arslan Ayub, Adeel Razzaq, Muhammad Salman Aslam, Hanan Iftekhar. 2013. A Conceptual Framework on Evaluating SWOT Analysis as the Mediator in Strategic Marketing Planning Through Marketing Intelligence. European Journal of Business and Social Sciences 2 (1); 91-98.

[4] Dijana Oreski. 2012. Strategy development by using SWOT-AHP. TEM Journal 1 (4); 283-291. 
[5] Fajar Nuraini Dwi Fatimah. 2017. Tehnik Analisa SWOT. Jakarta: Anak Hebat Indonesia.

[6] Fandy Tjiptono dan Gregorius Chandra. 2012. Pemasaran Strategik. Yogyakarta: Andi Offset.

[7] Ferdinand, Augusty, 2000. "Manajemen Pemasaran: Sebuah Pendekatan Strategy". Research Paper Series. No. 01 Program Magister ManajemenUniversitas Diponegoro (Maret).

[8] Freddy Rangkuti. 2015. Analisa SWOT: Tehnik Membedah Kasus Bisnis Analisa SWOT. Jakarta: Gramedia Pustaka Utama.

[9] Gary Dessler. 2016. Manajemen Sumber Daya Manusia. Jakarta: Indeks.

[10] Gomatesh M. Ravanavar and Poornima M. Charantimath. 2012. Strategic Formulation Using TOWS Matrix- A Case Study. International Journal of Research and Development 1 (1); 2- 9.

[11] Ifediora Christian Osita, Idoko Onyebuchi R, and Nzekwe Justina. 2014. Organizational's stability and productivity: the role of SWOT analysis an acronym for strength, weakness, opportunities, and threat. International Journal of Innovative and Applied Reseach 2 (9); 23-32.

[12] Joko Purwono, Sri Sugyaningsih, Rara Tama Putri. 2015. Strategi Pengembangan Bisnis Rumah Tempe Indonesia di Kota Bogor, Propinsi Jawa Barat. Jurnal NeO-Bis 9 (1); $60-71$.

[13] Kasmir. 2010. Pengantar Manajemen Keuangan. Jakarta: Prenadamedia Group.

[14] Muatasim Anwar Ahmed Al Salmi dan Norlena Bt Hasnan. 2015. SWOT and TOWS matrix e-Government analysis review on Sultanate of Oman. International Journal of Learning \& Development 5 (4); 13-23.

[15] Nura Abubakar \& Garba Bala Bello. 2013. Strengths, Weaknesses, Opportunities, and Threats (SWOT) Analysis on Globacom Ltd. International Journal of Information Technology and Business Management 16 (1); 83-91.

[16] Rio F. Wilantara dan Susilawati. 2016. Strategi \& Kebijakan Pengembangan UMKM. Upaya Meningkatkan Daya Saing UMKM Nasional di Era MEA. Bandung: Refika Aditama.

[17] Sofjan Assauri. 2016. Manajemen Operasi Produksi. Pencapaian Sasaran Organisasi Berkesinambungan. Jakarta: Rajagrafindo Persada.

[18] Xia Chan. 2011. A SWOT Study of the Development Strategy of Haier Group as One of the Most Successful Chinese Enterprises. International Journal of Business and Social Science 2 (11); 147-153.

\section{Appendix}

Table 2. IFE Analysis

\begin{tabular}{llccc}
\hline No & Indicator & $\begin{array}{c}\text { Weight } \\
(\mathrm{W})\end{array}$ & $\begin{array}{c}\text { Rating } \\
(\mathrm{R})\end{array}$ & $\mathrm{W} \times \mathrm{R}$ \\
\hline & Strength: & & & \\
\hline 1. & Number of inventory is adequate & 0.02 & 3 & 0.09 \\
\hline 2. & Knowing the cost of working capital for production & 0.02 & 3 & 0.06 \\
\hline 3. & There are pricing and profit methods & 0.03 & 3 & 0.09 \\
\hline 4. & Facing competition from other businesses & 0.03 & 3 & 0.09 \\
\hline 5. & Easily obtained & 0.02 & 3 & 0.06 \\
\hline
\end{tabular}




\begin{tabular}{|c|c|c|c|c|}
\hline No & Indicator & $\begin{array}{l}\text { Weight } \\
\text { (W) }\end{array}$ & $\begin{array}{l}\text { Rating } \\
\text { (R) }\end{array}$ & $\mathrm{W} \times \mathrm{R}$ \\
\hline & Score & 0.12 & & 0.39 \\
\hline & Weakness & & & \\
\hline 1. & Employee planning & 0.03 & 3 & 0.09 \\
\hline 2. & Employee recruitment process as needed & 0.03 & 3 & 0.09 \\
\hline 3. & Task assignment in writing & 0.02 & 2 & 0.04 \\
\hline 4. & Organization/coordination & 0.02 & 2 & 0.04 \\
\hline 5. & Employee development & 0.02 & 3 & 0.06 \\
\hline 6. & Wage/salary & 0.02 & 3 & 0.06 \\
\hline 7. & Incentives & 0.02 & 2 & 0.04 \\
\hline 8. & Other rewards & 0.02 & 3 & 0.06 \\
\hline 9. & Health insurance & 0.03 & 3 & 0.09 \\
\hline 10. & Working hours & 0.03 & 3 & 0.09 \\
\hline 11. & Work supervision & 0.02 & 3 & 0.06 \\
\hline 12. & Sanction & 0.03 & 3 & 0.09 \\
\hline 13. & Availability of machinery/equipment & 0.02 & 3 & 0.06 \\
\hline 14. & Consistent work steps & 0.03 & 3 & 0.09 \\
\hline 15. & Inventory is good & 0.02 & 2 & 0.04 \\
\hline 16. & Recording of every business transaction & 0.02 & 3 & 0.06 \\
\hline 17. & Every business transaction with a computer & 0.03 & 3 & 0.09 \\
\hline 18. & There are documents for business transactions & 0.03 & 3 & 0.09 \\
\hline 19. & There is a plan for income and expenditure & 0.02 & 2 & 0.04 \\
\hline 20. & There is separation of assets and owner and business debt & 0.02 & 2 & 0.04 \\
\hline 21. & Participate in financial report training & 0.03 & 3 & 0.09 \\
\hline 22. & Borrow money from a bank or financial institution & 0.02 & 3 & 0.06 \\
\hline 23. & Saving money at the bank & 0.02 & 3 & 0.06 \\
\hline 24. & Always check business finances & 0.02 & 2 & 0.04 \\
\hline 25. & Keep up with technology & 0.02 & 3 & 0.06 \\
\hline 26. & There are variations in the taste of the products & 0.03 & 3 & 0.09 \\
\hline 27. & There are variations of packaging and size & 0.03 & 3 & 0.09 \\
\hline 28. & Good quality of raw materials & 0.02 & 2 & 0.04 \\
\hline 29. & Paying attention to the health of consumers & 0.02 & 2 & 0.04 \\
\hline 30. & Price variations & 0.02 & 2 & 0.04 \\
\hline 31. & Price list & 0.02 & 2 & 0.04 \\
\hline 32. & The availability of transaction facilities & 0.02 & 2 & 0.04 \\
\hline 33. & Promotional activities & 0.03 & 3 & 0.09 \\
\hline 34. & There are several promo offers & 0.03 & 3 & 0.09 \\
\hline 35. & Trademarks are registered & 0.03 & 3 & 0.09 \\
\hline 36. & There is a profit growth compared to the previous year & 0.02 & 2 & 0.04 \\
\hline \multirow[t]{4}{*}{37.} & $\begin{array}{l}\text { There is a growth of sales volume compared to the previous } \\
\text { year }\end{array}$ & 0.02 & 2 & 0.04 \\
\hline & Score & 0.88 & & 2.36 \\
\hline & Total & 1.00 & & 2.75 \\
\hline & \multicolumn{4}{|l|}{ Table 3. EFE Analysis } \\
\hline No & Indicator & Weight & Rating & $\mathrm{W} \times \mathrm{R}$ \\
\hline
\end{tabular}




\begin{tabular}{|c|c|c|c|c|}
\hline & & $(\mathrm{W})$ & $(\mathrm{R})$ & \\
\hline \multicolumn{5}{|c|}{ Opportunity } \\
\hline 1. & The ease of getting suppliers & 0.12 & 3 & 0.36 \\
\hline 2. & Affected by natural situations & 0.12 & 3 & 0.36 \\
\hline 3. & The bargaining power of the buyers is relatively high & 0.07 & 3 & 0.21 \\
\hline 4. & The bargaining power of the suppliers is relatively high & 0.07 & 3 & 0.21 \\
\hline \multirow[t]{3}{*}{5.} & There is support from the Regency Government & 0.12 & 3 & 0.36 \\
\hline & Score & 0.50 & & 1.50 \\
\hline & Challenges & & & \\
\hline 1. & Support from the State-Owned Enterprises & 0.13 & 3 & 0.39 \\
\hline 2. & Other supports & 0.14 & 3 & 0.42 \\
\hline 3. & $\begin{array}{l}\text { An increase in the percentage of market share compared } \\
\text { to the previous year. }\end{array}$ & 0.10 & 2 & 0.20 \\
\hline \multirow[t]{3}{*}{4.} & $\begin{array}{l}\text { An increase in customer satisfaction compared to the } \\
\text { previous year }\end{array}$ & 0.13 & 2 & 0.26 \\
\hline & Score & 144 & & 1.27 \\
\hline & Total & 0.50 & & 2.77 \\
\hline
\end{tabular}

Source: the results of data processing 